Plant Tissue Cult. \& Biotech. 16(1): 25-29, 2006 (June)

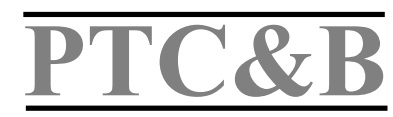

\title{
Comparative Studies on Field Performance of Micropropagated and Conventionally Propagated Sugarcane Plants
}

\author{
Neeru Sood ${ }^{1}$, Piyush Kumar Gupta ${ }^{2}$, R.K. Srivastava ${ }^{3}$ and \\ S.S. Gosal
}

REH Center, Nahar Sugar and Allied Industries Ltd., Pubjab, India

Key words: Comparative studies, Field performance, Sugarcane, Micropropagation

\begin{abstract}
The tissue culture derived sugarcane var. CoJ 64 plants attained better height, millable cane height and a greater number of live buds to conventionally raised plants. Further, the plants raised in vitro showed $13.2 \%$ increase in cane yield and $11.03 \%$ sugar recovery as compared to conventionally propagated sugarcane under parallel agronomic practices in the field, advocating suitability of seed cane programmed through tissue culture.
\end{abstract}

\section{Introduction}

Conventional propagated of sugarcane through offsets is slow, usually one to ten in a period of one year. Moreover, pathogens keep on accumulating generation after generation, which reduces the yield and quality of sugarcane. Therefore, efficient propagation system is required for mass multiplication of sugarcane. Micropropagation through tissue culture holds great potential for mass multiplication and subsequent rejuvenation and quality production of sugarcane.

The present investigation was carried out to micropropagate sugarcane plants and evaluate their field performance in different locations of the Pubjab and at Sugarcane Breeding Institute, Kamal (Haryana).

\section{Materials and Methods}

The spindle segments of sugarcane var. CoJ 64 were procured from the healthy plants grown in the experimental plots of the Department of Plant Breeding, Genetics and Biotechnology, PAU, Ludhiana. The micropropagation protocol developed by Gosal et al. (1998) was followed. The spindle explants were thoroughly washed with Teepol and Savlon for 10 to $15 \mathrm{~min}$ and then washed with running tap water; these spindles were then surface sterilized with $0.1 \%$

3Department of Horticulture, GBPUA\&T, Udham Singh Nagar, Uttranchal, India. ${ }^{4}$ Department of Plant Breeding, Genetics and Biotechnology, PAU, Punjab, India. 
$\mathrm{HgCl}_{2}$ for 10 min under the laminar air flow cabinet and washed thrice with autoclaved distilled water to remove traces of the disinfectant. The leaf sheaths around the spindle were removed aseptically with the help of a pair of forceps and a scalpel blade. Long spindles $(1.5-2.0 \mathrm{~cm})$ were inoculated on agar solidified MS supplemented with IAA, BAP and GA 3 (0.5 mg/1 each). Upon establishment, they were transferred to liquid multiplication medium fortified with BAP and $\mathrm{Kn}$ each with a concentration $0.5 \mathrm{mg} / \mathrm{l}$. Clumps of sugarcane propagules thus obtained were further multiplied and maintained on the same medium by regular subculturing at 15 days, interval to generate sufficient plants for commercial planting.

The shoots were then elongated on half strength agar gelled MS basal medium and subsequently rooted on liquid MS fortified with NAA (5.0 mg/l) and high concentration of sucrose $(7 \%)$. These micropropagated plantlets were hardened and planted in polybags and kept inside the poly house for acclimation. This micropropagated sugarcane var. CoJ 64 was planted in several locations in the district of Patiala, Mirpur and Fatehgarh Sahib. They were planted in November at a planting distance of 3 by 2 feet. The agronomic characters were recorded in August of the following TSS and Yield along with sugar recovery were recorded at the harvesting time (November).

\section{Results and Discussion}

The spindle cultures of sugarcane var. $\mathrm{CoJ} 64$ was established on MS fortified with IAA $(0.5 \mathrm{mg} / \mathrm{l})$, BAP $(0.5 \mathrm{mg} / \mathrm{l})$ and $\mathrm{GA}_{3}(0.5 \mathrm{mg} / \mathrm{l})$. Shoot regeneratyion occurred within 12 to 15 days of inoculation, thereby suggesting establishment of shoots cultures. Buds that sprouted from the nodal region were excised and the actively growing shoots were transferred to liquid shoot multiplication medium. The drying tips and the base of the explants turned brownish black due to the release of phenolics. The explants in culture usually released phenolics causing browning of the medium but this browning did not hamper the shoot proliferation.

The transfer of proliferaing clumps to half strength basal medium devoid of hormones exerted a strong influence leading to elongation of shoots with 15 to 20 days. Base of the clumps produced heavy roots within 10 to 12 days upon their transfer to the rooting medium. Plants were transferred to polybags with a survival rate of $94 \%$. In an earlier stuides Dhaliwal et al. (1997a, b) reported several factors affecting hardening of the micropropagated sugarcane.

The plants in culture were basically free from diseases and showed rejuvenation. These first generation canes were of exceptional quality as seed cane. The plantlets grew early and within a short time abundant numbers of tillers developed in a synchronous manner. 
Table 1 gives the summarized observations on the agronomic parameters studied in one year tissue cultured sugarcane grown in Patiala, Fatehgarh Sahib district of Pubjab and the Sugarcane Breeding Institute, Karnal, Haryana. The statistical analysis elucidates significance of differences between various characters in the five planting regions. A perusal of Table 1 shows that the plant height of the tissue cultured sugarcane is significantly higher than that of offsets raised sugarcanes. Tissue cultured plants attained heights of $240 \mathrm{~cm}$ at Sugarcane Breeding Institute, Karnal, $206.75 \mathrm{~cm}$ at Mirpur and $206.25 \mathrm{~cm}$ at Fatehgarh division Bhari, values that were significatnly higher than offsets raised plants $(185.6 \mathrm{~cm})$. However, tissue cultured plants at Dhuri attained only a height of $167.5 \mathrm{~cm}$ because the crop was not properly irrigated by the growers.

Table 1. Observations taken on random clumps of one year old micropropagated sugarcane variety CoJ 64 grown at different locations in the Punjab and the Sugacane Breeding Institute, Haryana.

\begin{tabular}{|c|c|c|c|c|c|c|c|}
\hline Location & $\begin{array}{l}\text { Height } \\
(\mathrm{cm})\end{array}$ & $\begin{array}{l}\text { Periphery } \\
\text { of cane } \\
(\mathrm{cm})\end{array}$ & $\begin{array}{l}\text { No. of } \\
\text { nodes }\end{array}$ & $\begin{array}{l}\text { No. of } \\
\text { canes/ } \\
\text { clumps }\end{array}$ & $\begin{array}{c}\text { Internodal } \\
\text { distance } \\
(\mathrm{cm})\end{array}$ & $\begin{array}{c}\text { Yield } \\
\text { (qt./plot) }\end{array}$ & $\begin{array}{c}\text { Sugar } \\
\text { recovery } \\
(\%)\end{array}$ \\
\hline $\begin{array}{l}\text { Baran } \\
\text { (Pubjab) }\end{array}$ & 191.15 & 7.58 & 16.2 & 14.4 & 12.3 & 60.5 & 9.14 \\
\hline $\begin{array}{l}\text { Mirpur } \\
\text { (Fatehgarh } \\
\text { Sahib) }\end{array}$ & 206.75 & 6.4 & 14.5 & 22.0 & 12.5 & 64.3 & 9.75 \\
\hline $\begin{array}{l}\text { Fatehgarh div. } \\
\text { Barhi } \\
\text { (Fatehgarh } \\
\text { Sahib) }\end{array}$ & 206.25 & 8.12 & 16.8 & 15.7 & 9.8 & 63.6 & 9.34 \\
\hline $\begin{array}{l}\text { Dhuri } \\
\text { (Patiala) }\end{array}$ & 167.5 & 7.8 & 11.7 & 11.3 & 11.8 & 57.7 & 8.7 \\
\hline $\begin{array}{l}\text { Control } \\
\text { (Raised from } \\
\text { offsets) }\end{array}$ & 185.6 & 7.9 & 15.0 & 12.8 & 10.3 & 56.8 & 8.52 \\
\hline $\begin{array}{l}\text { Sugarcane } \\
\text { Breeding } \\
\text { Institutre, } \\
\text { Karnal }\end{array}$ & 240.0 & 12.2 & 30.0 & 7.0 & 9.1 & 62.6 & 9.46 \\
\hline $\mathrm{CD}(\%)$ & 0.524 & 0.157 & 0.736 & 0.964 & 0.3765 & 0.3765 & 0.1982 \\
\hline $\mathrm{CV}$ & 8.507 & 8.954 & 13.347 & 27.05 & 10.591 & 12.423 & 7.467 \\
\hline
\end{tabular}

The individual value in the Table 1 represent means of five canes or clumps.

The periphery of the tissue cultured plants was smaller than that of offsets raised sugarcane plants except in the sugarcane plants at Fatehgarh division Barhi and the Sugarcane Breeding Institute, Karnal where plants had maximum periphery $(12.2 \mathrm{~cm})$. High tillering might have resulted in thinner canes because thickness of the canes is directly proportional to the number of tillers per clump and is also related to the cytokinin effect. Moreover, it is a recognized fact that 
the tissue cultured plants in the first year in thinner and thickness increases in ratoon and subsequent generations.

The tissue cultured plants possessed a higher number of nodes with a higher internode distance. Barring Dhuri plantation where the number of nodes wer significantly lower than offsets raised plantation (15), the rest of the plantation at all sites showed a higher number of nodes. Internodal distance at Fatehgarh was $9.8 \mathrm{~cm}$ and at the sugarcane Breeding Institute, Karnal it was $9.1 \mathrm{~cm}$ and was lower $(10.3 \mathrm{~cm})$ than offset type plantations whereas plantations at other locations showed higher internodal distance (Table 1).
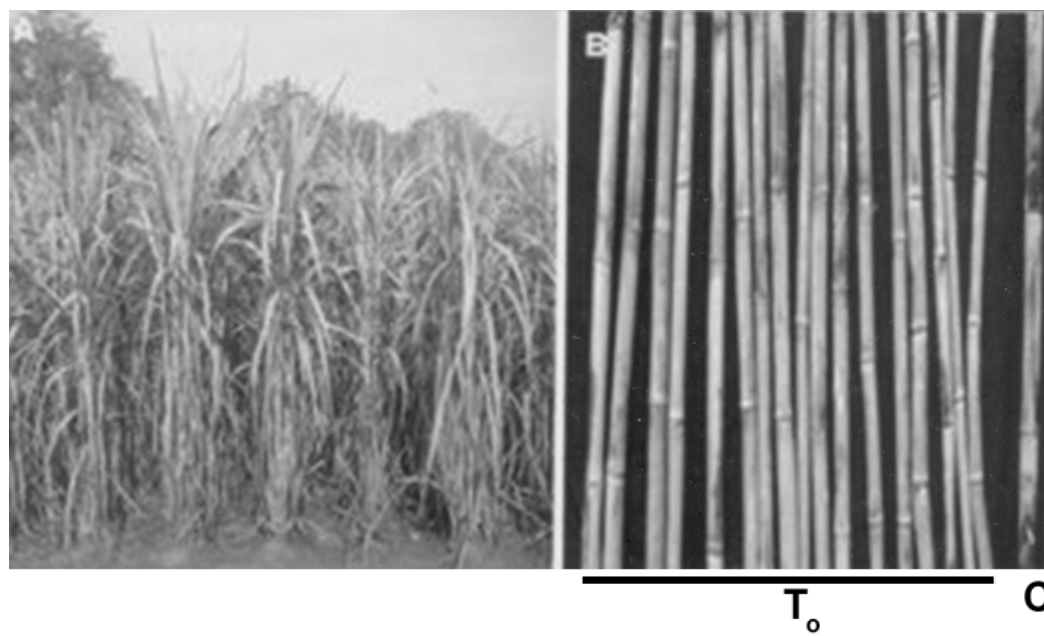

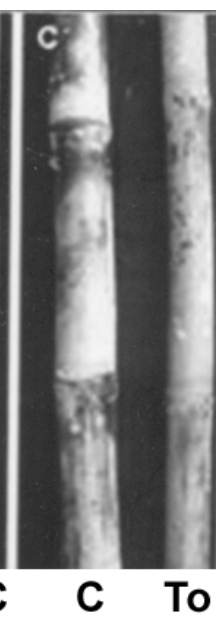

Plate 1. Field grown micropropagated sugarcane and internodal, girth and colour differences between conventional and micropropagated sugarcane.

In general, because of the thinner dia of canes tissue cultured plantation contained a greater number of canes per clump. Number of canes was highest, i.e. 22 in Mirpur plantation followed by 15.7 canes per clump at Fatehgarh whereas offsets raised plantation had a average of 12.8 canes per clump; at the Sugarcane Breeding Institute, Karnal the number was 7 canes per clump. Sreenivasan and Sreenivasan (1992) reported that smaller diameter is more than compensated by large increament in millable cane population, which resulted in an increase of tonnage. They further reported significant variation in cane number per clump in untreated and tissue cultured canes. Furthermore, tillering to the extent of 18 tillers per plantlets was noted by Hendre et al. (1983) in meristem cultured Cp 740 plantations. The yield of tissue cultured plants was in general higher than conventionally propagated plants. The yield as against 56.8 $\mathrm{qt} /$ plot in control the yield was $64.3 \mathrm{qt} /$ plot in tissue cultured derived material at Mirpur followed by $63.6 \mathrm{qt} / \mathrm{plot}$ at Barhi division and $62.2 \mathrm{qt} / \mathrm{plot}$ at the Sugarcane Breeding Institute, Karnal. This could be attributed to a greater 
number of canes per clump in tissue cultured plants. The sugar recovery percentage also showed higher values for micropropagated plants than the control. The maximum sugar recovery in vitro propagated plants at Mirpur was $9.75 \%$ followed by $9.46 \%$ at the Sugarcane Breeding Institute, Karnal and $9.34 \%$ at Barhi division. On the other hand, sugar recovery was only $8.52 \%$ in the control. Kilaru and Aruna (1998) reported higher rate of sugar recovery in micropropagated plants as compared to the control.

Adoptation of tissue culture methods brought about substantial improvement in that material was free from diseases and grew vigorously contributing to a greater productivity.

Micropropagation ensures tree to type and rapid multiplication of disease free material and as such can be used as super elite seed stock for quick spread of new varieties and rejuvination of old ones of sugarcane. First year planted canes are used for cane seed program and for higher tonnage as they give more tillers per clump.

\section{References}

Dhaliwal RK, Malik CP, Gosal SS and Dhaliwal LS (1997a) Studies on hardening of micropropagated sugarcane (Saccharum officinarum L.) plantlets. I. Root and shoot parameters. Ann. Bio. 13(1): 21-25.

Dhaliwal RK, Malik CP, Gosal SS and Dhaliwal LS (1997b) Studies on hardening of micropropagated sugarcane (Saccharum officinarum L.) plantlets. II. Leaf parameters and biochemical estimation. Ann. Bio. 13(1): 15-20.

Gosal SS, Thind KS and Dhaliwal HS (1998) Micropropagation of sugarcane - An efficient protocol for commercial plant production. Crop Improv. 25: 1-5.

Hendre RR, Iver RS and Kotwal M (1983) Rapid multiplication of sugarcane by tissue culture. Sugarcane 1: 5-8.

Kilaru and Aruna (1998) Micropropagation of sugarcane - A commercial approach. Proc. 60th Annual Convention of Sugarcane Technologists Association of India. pp. 81-86.

Steenivasan TS and Sreenivasan J (1992) Micropropagation of sugarcane varieties for increasing cane yield. SISSTA Sugar. J. 18(4): 61-64. 